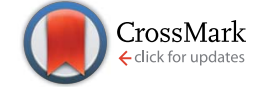

Cite this: RSC Adv., 2017, 7, 606

Received 7th October 2016

Accepted 14th November 2016

DOI: $10.1039 / c 6 r a 24834 a$

www.rsc.org/advances

\title{
TEMPO-catalyzed oxidative homocoupling route to 3,2'-biindolin-2-ones via an indolin-3-one intermediate $\uparrow$
}

\author{
Bo Yin, Panpan Huang, Yingbing Lu* and Liangxian Liu* \\ A combinative C2-selective arylation, and C3-selective carbonylation of free indole derivatives, by means of \\ TEMPO catalysis and a silver oxidant under non-directing group conditions, was successful demonstrated. \\ This new methodology is both atom and step efficient and is applicable to a broad scope of substrates, \\ allowing the synthesis of a range of synthetically valuable $3,2^{\prime}$-biindolin-2-ones in moderate to excellent \\ yields.
}

\section{Introduction}

Biindole scaffolds are important motifs in an array of natural products with diverse biological activities, ${ }^{1-3}$ exemplified by the TCDD (2,3,7,8-tetrachlorodibenzo- $p$-dioxin) antagonist bisindigotin 1 (Fig. 1) from the Chinese medicinal herb Isatis indigotica. ${ }^{4}$ This herbal plant has long been used as a folk medicine in China for treatment of viral diseases and diseases with an inflammatory nature. ${ }^{4}$ In addition, indirubin, a bis-indole scaffold and its derivatives, are present in some traditional Chinese medicines and inhibit cyclin-dependent kinases (CDKs). ${ }^{5}$ These medicines have historically been used to treat chronic diseases including leukemia. ${ }^{6}$

Accordingly, synthesis and functionalization of biindolyls have attracted much attention over decades. ${ }^{7-9}$ Recently, some progress on construction of the $2,3^{\prime}$-linked $^{7}$ and $3,3^{\prime}$-linked $^{8}$ biindolyl scaffolds was made, including the palladium- or copper-catalyzed intermolecular coupling reaction and iodineinduced dimerization of indoles. For example, Zhang and coworkers reported a mild and selective method for dimerization of indoles by palladium catalysis to give 2,3'-biindolyls in high yields at room temperature. ${ }^{9 b}$ However, most of these procedures require expensive metal catalysts and high loading of metal oxidants. In addition, the regioselectivity control of C2 arylation can be quite challenging under non-directing group conditions. From the viewpoints of atom economy, cost efficiency and green chemistry, atmospheric oxygen is obviously superior to other reagents, and thus represents the quintessential oxidant. ${ }^{10}$ In the past decades, most efforts have been

Key Laboratory of Organo-Pharmaceutical Chemistry of Jiangxi Province, Gannan Normal University, Ganzhou 341000, PR China.E-mail: lxliu@xmu.edu.cn $\dagger$ Electronic supplementary information (ESI) available: Experimental section and NMR data of the prepared compounds. CCDC 1453369. For ESI and crystallographic data in CIF or other electronic format see DOI: 10.1039/c6ra24834a directed to the development of transition metal-based catalysts. In contrast, much less attention has been paid to the development of non-metallic oxidation systems, largely ignoring their inherent advantages. ${ }^{10 c}$ The radical TEMPO (2,2,6,6-tetramethylpiperidine 1-oxyl radical) and its derivatives are wellestablished catalysts for oxidation processes, and now used extensively in organic synthesis and industrial applications as a mild, safe, and economical alternative to heavy metal reagents as highly selective oxidation catalysts for the production of pharmaceuticals, flavors, fragrances, agrochemicals, and a variety of other specialty chemicals. ${ }^{11}$ As part of our ongoing investigations on environmentally benign, selective, and controllable $\mathrm{C}-\mathrm{H}$ bond functionalization, we studied the TEMPO-catalyzed oxidative homocoupling of indoles in air. ${ }^{12}$ Herein, we report the first successful example of TEMPOcatalyzed oxidative homocoupling of indoles affording substituted C2-C3' bisindole-3-ones 9 (Scheme 1).

\section{Results and discussion}

Preliminary studies were carried out at $80{ }^{\circ} \mathrm{C}$ in an open tube, using commercially available unsubstituted indole (5a) in the presence of TEMPO and $\mathrm{K}_{3} \mathrm{PO}_{4}$. A variety of transition-metal catalysts, including $\mathrm{FeCl}_{3} \cdot 6 \mathrm{H}_{2} \mathrm{O}, \mathrm{FeSO}_{4}, \mathrm{ZrCl}_{4}, \mathrm{ZnCl}_{2}, \mathrm{CoCl}_{2}$, $\mathrm{CuI}, \mathrm{CuCl}$, and $\mathrm{Ag}_{2} \mathrm{CO}_{3}$, were screened. It was found that $\mathrm{Ag}_{2} \mathrm{CO}_{3}$ was the most efficient catalyst for this reaction, which gave the desired product 9a in 51\% yield (Table 1, entry 8); while other transition-metal catalysts did not undergo the conversion under the reaction conditions. The structure of 9a was confirmed by X-ray crystallography (see ESI $\dagger$ ). Among silver sources tested, including $\mathrm{Ag}_{2} \mathrm{CO}_{3}, \mathrm{AgNO}_{3}, \mathrm{AgOTf}$, and $\mathrm{AgBF}_{4}$, were tested in DMF using TEMPO as the oxidant at $80{ }^{\circ} \mathrm{C}$ for $12 \mathrm{~h}$, and $\mathrm{Ag}_{2} \mathrm{CO}_{3}$ was found to be the most effective catalyst (Table 1, entries 8-12). The amount of $\mathrm{Ag}_{2} \mathrm{CO}_{3}$ also has a large influence on the yield of 9a. In the absence of $\mathrm{Ag}_{2} \mathrm{CO}_{3}$ catalyst, the desired product was not obtained under these conditions, whereas, at 


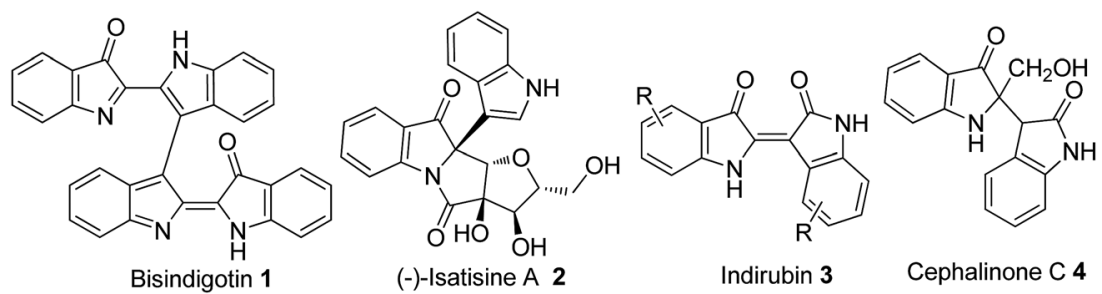

Fig. 1 Representative natural products with a 2-substituent indolin-3-one structural unit.

$35 \mathrm{~mol} \%$ of $\mathrm{Ag}_{2} \mathrm{CO}_{3}$, the desired product is obtained in $57 \%$ yield, and at lower or higher loading, the yield decreases (Table 1, entries 12-16). It was also found that the use of TEMPO as an oxidant is critical to the reaction. In the absence of TEMPO, the homocoupling reaction did not proceed. However, the slightly more loading amounts of TEMPO result in a dramatic influence on the yield (Table 1, entries 17-20). For example, $81 \%$ yield of 9a was obtained when using $0.15 \mathrm{~mol} \%$ of TEMPO (Table 1, entry 19). Further assessment of the reaction solvents indicated that DMF was the optimal solvent, while other solvents gave lower yields or were ineffective (Table 1, entries 21-25).

Finally, we examined a series of bases (Table 1, entries 2629). The observation revealed that NaOAc is slightly better than $\mathrm{K}_{3} \mathrm{PO}_{4}$ and other bases, such as $\mathrm{LiOH}, \mathrm{NaHCO}_{3}$, and $\mathrm{K}_{2} \mathrm{CO}_{3}$, are inferior to $\mathrm{K}_{3} \mathrm{PO}_{4}$. After a great deal of screening on different parameters we found that the combinative C2-selective arylation and C3-selective carbonylation of indole by using TEMPO (15 mol\%) in air as catalyst, $\mathrm{Ag}_{2} \mathrm{CO}_{3}(35 \mathrm{~mol} \%$ ) as an oxidant, and $\mathrm{NaOAc}(10 \mathrm{~mol} \%)$ as base in DMF at $80^{\circ} \mathrm{C}$ led to the highest efficiency ( $87 \%$ yield, Table 1 , entry 26 ).

With a set of optimized conditions in hand, we next examined the indole scope of this TEMPO-catalyzed oxidative homocoupling reaction. As shown in Table 2, the reaction can tolerate a variety of functional groups at the $4,5,6$, and 7 positions of indoles, such as $\mathrm{F}, \mathrm{Cl}, \mathrm{Br}, \mathrm{CH}_{3}, \mathrm{CH}_{3} \mathrm{O}, \mathrm{BnO}$, $\mathrm{CO}_{2} \mathrm{CH}_{3}$, and $\mathrm{CN}$, and the corresponding reactions proceeded smoothly to afford the desired products in moderate to excellent yields with high regioselectivity. The substituent effect on the indole ring was then investigated. The results have shown that electronegativities of substituents played a major role in

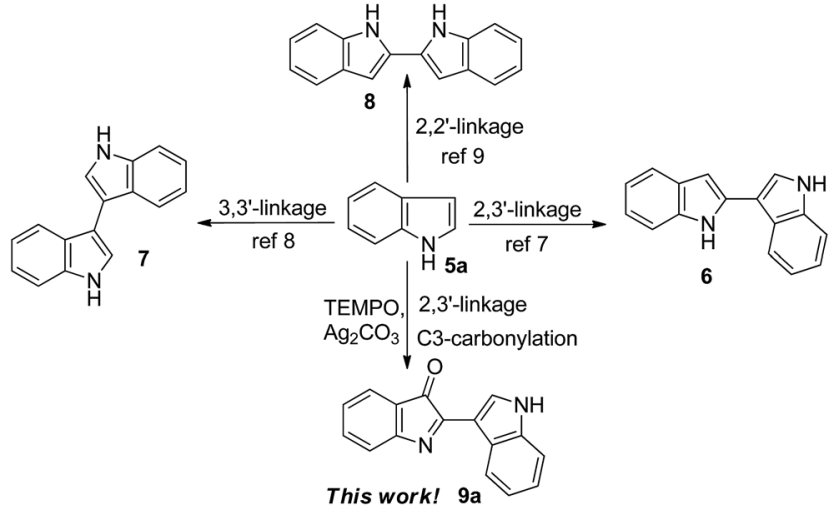

Scheme 1 Homocoupling of indole. governing the reactivity of the substrates. Electron-donating substitutents showed better results than electron-withdrawing substitutents in this transformation. For example, 7substituted indole derivatives with electron-donating substituents $\left(\mathrm{CH}_{3}, \mathrm{OCH}_{3}\right.$, and $\left.\mathrm{OBn}\right)$ afforded the desired 9l-n in yields ranging from $76 \%$ to $90 \%$, while 7 -substituted indole derivatives with electron-withdrawing substituents ( $\mathrm{Cl}$ and $\mathrm{Br}$ )

Table 1 Optimization of the reaction conditions ${ }^{a}$

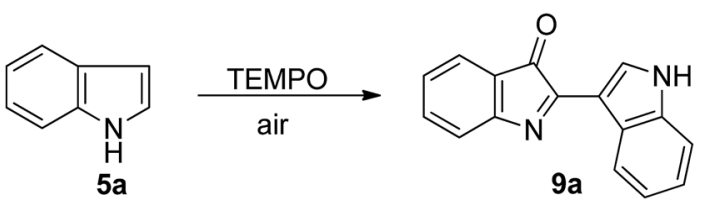

\begin{tabular}{|c|c|c|c|c|c|}
\hline Entry & $\begin{array}{l}\text { Catalyst } \\
\text { (mol\%) }\end{array}$ & $\begin{array}{l}\text { TEMPO } \\
(\mathrm{mol} \%)\end{array}$ & Solvent & $\begin{array}{l}\text { Base } \\
(\mathrm{mol} \%)\end{array}$ & $\begin{array}{l}\text { Yield }^{b} \\
(\%)\end{array}$ \\
\hline 1 & $\mathrm{FeCl}_{3} \cdot 6 \mathrm{H}_{2} \mathrm{O}(15)$ & 10 & $\mathrm{DMF}$ & $\mathrm{K}_{3} \mathrm{PO}_{4}(10)$ & 0 \\
\hline 2 & $\mathrm{FeSO}_{4}(15)$ & 10 & DMF & $\mathrm{K}_{3} \mathrm{PO}_{4}(10)$ & 0 \\
\hline 3 & $\mathrm{ZrCl}_{4}(15)$ & 10 & $\mathrm{DMF}$ & $\mathrm{K}_{3} \mathrm{PO}_{4}(10)$ & 0 \\
\hline 4 & $\mathrm{ZnCl}_{2}(15)$ & 10 & DMF & $\mathrm{K}_{3} \mathrm{PO}_{4}(10)$ & 0 \\
\hline 5 & $\mathrm{CoCl}_{4}(15)$ & 10 & DMF & $\mathrm{K}_{3} \mathrm{PO}_{4}(10)$ & 0 \\
\hline 6 & Cul (15) & 10 & DMF & $\mathrm{K}_{3} \mathrm{PO}_{4}(10)$ & Trace \\
\hline 7 & $\mathrm{CuCl}_{2}(15)$ & 10 & $\mathrm{DMF}$ & $\mathrm{K}_{3} \mathrm{PO}_{4}(10)$ & Trace \\
\hline 8 & $\mathrm{Ag}_{2} \mathrm{CO}_{3}(15)$ & 10 & DMF & $\mathrm{K}_{3} \mathrm{PO}_{4}(10)$ & 51 \\
\hline 9 & $\mathrm{AgNO}_{3}(15)$ & 10 & $\mathrm{DMF}$ & $\mathrm{K}_{3} \mathrm{PO}_{4}(10)$ & 24 \\
\hline 10 & AgOTf (15) & 10 & $\mathrm{DMF}$ & $\mathrm{K}_{3} \mathrm{PO}_{4}(10)$ & 35 \\
\hline 11 & $\mathrm{AgBF}_{4}(15)$ & 10 & DMF & $\mathrm{K}_{3} \mathrm{PO}_{4}(10)$ & 22 \\
\hline 12 & - & 10 & DMF & $\mathrm{K}_{3} \mathrm{PO}_{4}(10)$ & 0 \\
\hline 13 & $\mathrm{Ag}_{2} \mathrm{CO}_{3}(5)$ & 10 & DMF & $\mathrm{K}_{3} \mathrm{PO}_{4}(10)$ & 10 \\
\hline 14 & $\mathrm{Ag}_{2} \mathrm{CO}_{3}(25)$ & 10 & $\mathrm{DMF}$ & $\mathrm{K}_{3} \mathrm{PO}_{4}(10)$ & 53 \\
\hline 15 & $\mathrm{Ag}_{2} \mathrm{CO}_{3}(35)$ & 10 & $\mathrm{DMF}$ & $\mathrm{K}_{3} \mathrm{PO}_{4}(10)$ & 57 \\
\hline 16 & $\mathrm{Ag}_{2} \mathrm{CO}_{3}(45)$ & 10 & DMF & $\mathrm{K}_{3} \mathrm{PO}_{4}(10)$ & 55 \\
\hline 17 & $\mathrm{Ag}_{2} \mathrm{CO}_{3}(35)$ & - & $\mathrm{DMF}$ & $\mathrm{K}_{3} \mathrm{PO}_{4}(10)$ & 0 \\
\hline 18 & $\mathrm{Ag}_{2} \mathrm{CO}_{3}(35)$ & 5 & DMF & $\mathrm{K}_{3} \mathrm{PO}_{4}(10)$ & 27 \\
\hline 19 & $\mathrm{Ag}_{2} \mathrm{CO}_{3}(35)$ & 15 & DMF & $\mathrm{K}_{3} \mathrm{PO}_{4}(10)$ & 81 \\
\hline 20 & $\mathrm{Ag}_{2} \mathrm{CO}_{3}(35)$ & 20 & DMF & $\mathrm{K}_{3} \mathrm{PO}_{4}(10)$ & 81 \\
\hline 21 & $\mathrm{Ag}_{2} \mathrm{CO}_{3}(35)$ & 15 & DMSO & $\mathrm{K}_{3} \mathrm{PO}_{4}(10)$ & 67 \\
\hline 22 & $\mathrm{Ag}_{2} \mathrm{CO}_{3}(35)$ & 15 & Toluene & $\mathrm{K}_{3} \mathrm{PO}_{4}(10)$ & 0 \\
\hline 23 & $\mathrm{Ag}_{2} \mathrm{CO}_{3}(35)$ & 15 & Pyridine & $\mathrm{K}_{3} \mathrm{PO}_{4}(10)$ & 0 \\
\hline 24 & $\mathrm{Ag}_{2} \mathrm{CO}_{3}(35)$ & 15 & 1,4-Dioxane & $\mathrm{K}_{3} \mathrm{PO}_{4}(10)$ & Trace \\
\hline 25 & $\mathrm{Ag}_{2} \mathrm{CO}_{3}(35)$ & 15 & $\mathrm{ClCH}_{2} \mathrm{CH}_{2} \mathrm{Cl}$ & $\mathrm{K}_{3} \mathrm{PO}_{4}(10)$ & 0 \\
\hline 26 & $\mathrm{Ag}_{2} \mathrm{CO}_{3}(35)$ & 15 & $\mathrm{DMF}$ & NaOAc (10) & 87 \\
\hline 27 & $\mathrm{Ag}_{2} \mathrm{CO}_{3}(35)$ & 15 & $\mathrm{DMF}$ & LiOH (10) & 0 \\
\hline 28 & $\mathrm{Ag}_{2} \mathrm{CO}_{3}(35)$ & 15 & $\mathrm{DMF}$ & $\mathrm{NaHCO}_{3}(10)$ & 30 \\
\hline 29 & $\mathrm{Ag}_{2} \mathrm{CO}_{3}(35)$ & 15 & DMF & $\mathrm{K}_{2} \mathrm{CO}_{3}(10)$ & 48 \\
\hline
\end{tabular}


Table 2 Substrate scope ${ }^{a}$

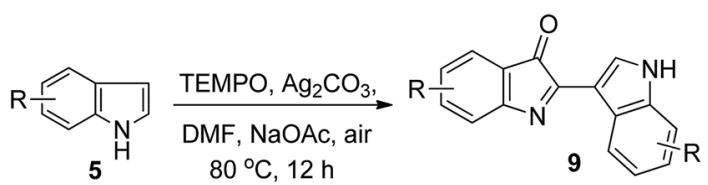

\begin{tabular}{|c|c|c|c|}
\hline Entry & $\mathrm{R}$ & Product & Yield $^{b}[\%]$ \\
\hline 1 & $\mathrm{H}$ & $9 a$ & 87 \\
\hline 2 & $5-\mathrm{F}$ & $9 b$ & 66 \\
\hline 3 & $5-\mathrm{Br}$ & $9 c$ & 75 \\
\hline 4 & $5-\mathrm{CH}_{3}$ & 9d & 89 \\
\hline 5 & $5-\mathrm{OCH}_{3}$ & $9 e$ & 71 \\
\hline 6 & $5-\mathrm{OBn}$ & 9f & 78 \\
\hline 7 & $6-\mathrm{F}$ & $9 g$ & 73 \\
\hline 8 & 6-Cl & $9 h$ & 64 \\
\hline 9 & 6- $-\mathrm{CH}_{3}$ & $9 i$ & 79 \\
\hline 10 & $7-\mathrm{Cl}$ & $9 j$ & 61 \\
\hline 11 & 7-Br & $9 k$ & 72 \\
\hline 12 & 7- $\mathrm{CH}_{3}$ & 91 & 90 \\
\hline 13 & 7- $\mathrm{OCH}_{3}$ & $9 m$ & 76 \\
\hline 14 & 7-OBn & $9 n$ & 82 \\
\hline 15 & $4-\mathrm{CN}$ & 90 & 38 \\
\hline 16 & $4-\mathrm{CO}_{2} \mathrm{CH}_{3}$ & $9 p$ & 63 \\
\hline
\end{tabular}

${ }^{a}$ Reaction conditions: indole $(0.3 \mathrm{mmol})$, TEMPO (15 mol\%), $\mathrm{Ag}_{2} \mathrm{CO}_{3}$ (35 mol\%), NaOAc (10 mol\%), DMF $(1 \mathrm{~mL}), 80^{\circ} \mathrm{C} .{ }^{b}$ Isolated yields.

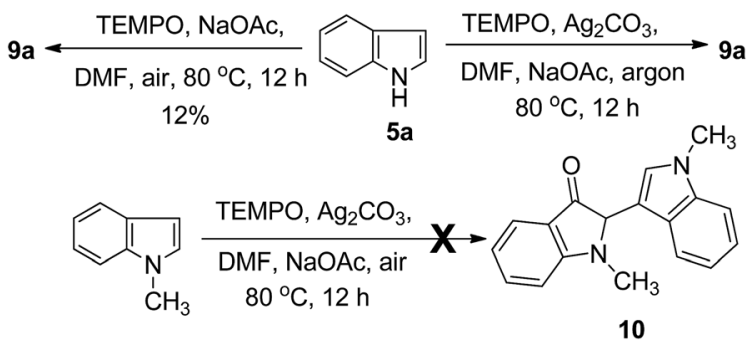

Scheme 2 Mechanistic studies.

provided the desired products in 61 and $72 \%$ yields, respectively. It is worth noting that substrate with a strong electronwithdrawing substitutents at C4-position, such as $\mathrm{CO}_{2} \mathrm{CH}_{3}$ and $\mathrm{CN}$, gave 90 and $9 \mathrm{p}$ in $63 \%$ and $38 \%$ yields, respectively. This is particularly important, since substrates with a strong electron-withdrawing group, such as a nitrile group, disfavored the homocoupling of indoles and there were few examples reported. ${ }^{7,8}$

To gain some mechanistic insight into the process of this reaction, a series of control experiments were conducted (Scheme 2). Because the TEMPO-catalyzed oxidative homocoupling reaction was performed in air, the role of $\mathrm{O}_{2}$ in this reaction was explored by conducting several control experiments. Under an $\mathrm{O}_{2}$ atmosphere, the reaction yield was not increased, but a more rapid conversion of the starting material to the reaction product was observed by TLC detection compared to that performed under air conditions. However, only trace amount of the product was obtained under an argon atmosphere, even a long reaction time. These results indicated

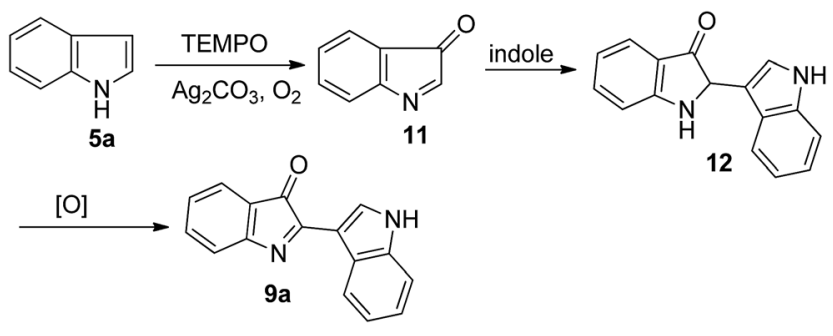

Scheme 3 Plausible reaction pathway.

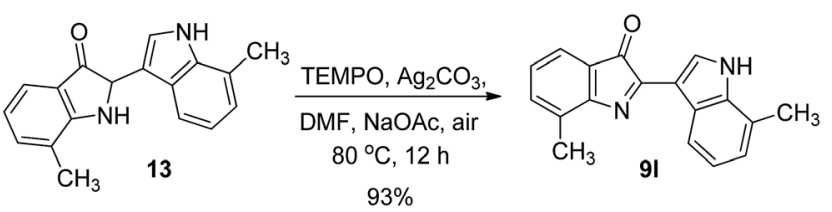

Scheme 4 Investigation of the reaction mechanism.

that $\mathrm{O}_{2}$ is essential for the TEMPO-catalyzed transformation. In addition, in the control experiment of 5a with TEMPO but without $\mathrm{Ag}_{2} \mathrm{CO}_{3}$, compound 9a was obtained only in $12 \%$ yield. The result indicated that $\mathrm{Ag}_{2} \mathrm{CO}_{3}$ act as terminal oxidant. Under the optimized conditions, $\mathrm{N}-\mathrm{CH}_{3}$ indole was chosen as a substrate instead of indole. To our surprise, no conversion was observed, indicating that the substituents at the N1position of the indole had a great influence on the reactivity.

Although the detailed mechanism remained unclear at the current stage, a plausible reaction pathway based on the basis of the results described above and relevant literature ${ }^{13}$ is outlined in Scheme 3. First, indole was oxidized slowly in the presence of TEMPO, $\mathrm{Ag}_{2} \mathrm{CO}_{3}$ and $\mathrm{O}_{2}$ into indenone 11 which should be unstable and was never isolated. ${ }^{13 a, d}$ Then, a rapid nucleophilic addition of another indole molecule on the $\mathrm{C}=\mathrm{N}$ bond of this intermediate gave the intermediate $\mathbf{1 2}$, which was oxidized rapidly to afford product 9 a.

To verify such a mechanistic scenario, we attempted to obtained the putative intermediate $\mathbf{1 2}$ or its derivatives. Fortunately, trace amounts of $\mathbf{1 3}$ can be determined in the reaction mixtures when 7-methyl- $1 H$-indole was subjected to the standard reaction conditions, which showed us some clues on the reaction intermediate. In the next step, to obtain more information concerning the reaction pathway, we separated and collected the intermediate 13, and subjected it to react with TEMPO under standard reaction conditions, and this gave product 91 in $93 \%$ yield (Scheme 4 ). This result showed that $\mathbf{1 3}$ is the intermediate of the dimeric reaction.

\section{Conclusions}

In conclusion, we have developed a general and efficient method for the synthesis of 3,2'-biindolin-2-ones via a TEMPOcatalyzed oxidative homo dimerization in moderate to excellent yields with high regioselectivity. The advantages of this new method are broad substrate scope, operational simplicity, and high atom-economy. Moreover, the high halogen compatibility 
of the process can provide a facile access to halo-substituted 3,2 '-biindolin-2-ones.

\section{Acknowledgements}

The authors are grateful to the NSF of China (No. 21462002), Natural Science Foundation of Jiangxi Province (No. 20161BAB203096) for financial support.

\section{Notes and references}

1 (a) R. J. Sundberg, Indoles, Academic Press, San Diego, 1996; (b) S. Cacchi and G. Fabrizi, Chem. Rev., 2005, 105, 28732920; (c) L. Joucla and L. Djakovitch, Adv. Synth. Catal., 2009, 351, 673-714; (d) M. Bandini and A. Eichholzer, Angew. Chem., Int. Ed., 2009, 48, 9608-9644; (e) G. Bartoli, G. Bencivenni and R. Dalpozzo, Chem. Soc. Rev., 2010, 39, 4449-4465; (f) F. Zhou, Y. L. Liu and J. Zhou, Adv. Synth. Catal., 2010, 352, 1381-1407.

2 (a) L. S. Feng, M. L. Liu, S. Zhang, Y. Chai, B. Wang, Y. B. Zhang, K. Lv, Y. Guan, H. Y. Guo and C. L. Xiao, Eur. J. Med. Chem., 2011, 46, 341-348; (b) S. Nam, A. Scuto, Y. Yang, W. Y. Chen, S. Park, H. S. Yoo, H. Konig, R. Bhatia, X. L. Cheng, K. H. Merz, G. Eisenbrand and R. Jove, Mol. Oncol., 2012, 6, 276-283; (c) Y. K. Chan, H. H. Kwok, L. Y. Chan, K. S. Y. Leung, J. Shi, N. K. Mak, R. N. S. Wong and P. Y. K. Yue, Biochem. Pharmacol., 2012, 83, 598-607; (d) S. Nam, W. Wen, A. Schroeder, A. Herrmann, H. Yu, X. L. Cheng, K. Z. Merz, G. Eisenbrand, H. Z. Li, Y. C. Yuan and R. Jove, Mol. Oncol., 2013, 7, 369-378.

3 (a) F. P. Guengerich, J. L. Sorrells, S. Schmitt, J. A. Krauser, P. Aryal and L. Meijer, J. Med. Chem., 2004, 47, 3236-3241; (b) K. Vougogiannopoulou, Y. Ferandin, K. Bettayeb, V. Myrianthopoulos, O. Lozach, Y. Z. Fan, C. H. Johnson, P. Magiatis, A. L. Skaltsounis, E. Mikros and L. Meijer, J. Med. Chem., 2008, 51, 6421-6431; (c) S. J. Choi, J. E. Lee, S. Y. Jeong, I. Im, S. D. Lee, E. J. Lee, S. K. Lee, S. M. Kwon, S. G. Ahn, J. H. Yoon, S. Y. Han, J. Kim and Y. C. Kim, J. Med. Chem., 2010, 53, 3696-3706; (d) C. Pergola, N. Gaboriaud-Kolar, N. Jestädt, S. König, M. Kritsanida, A. M. Schaible, H. K. Li, U. Garscha, C. Weinigel, D. Barz, K. F. Albring, O. Huber, A. L. Skaltsounis and O. Werz, J. Med. Chem., 2014, 57, 3715-3723.

4 X. Y. Wei, C. Y. Leung, C. K. C. Wong, X. Y. Shen, R. N. C. Wong, Z. W. Cai and N. K. Mak, J. Nat. Prod., 2005, 68, 427-429.

5 (a) R. Hoessel, S. Leclerc, J. A. Endicott, M. E. M. Nobel, A. Lawrie, P. Tunnah, M. Leost, E. Damiens, D. Marie, D. Marko, E. Niederberger, W. C. Tang, G. Eisenbrand and L. Meijer, Nat. Cell Biol., 1999, 1, 60-67; (b) V. Myrianthopoulos, P. Magiatis, Y. Ferandin, A. L. Skaltsounis, L. Meijer and E. Mikros, J. Med. Chem., 2007, 50, 4027-4037; (c) A. Beauchard, H. Laborie, H. Rouillard, O. Lozach, Y. Ferandin, R. L. Guevel,
C. Guguen-Guillouzo, L. Meijer, T. Besson and V. Thiery, Bioorg. Med. Chem., 2009, 17, 6257-6263.

6 Z. Xiao, Y. Hao, B. Liu and L. Qian, Leuk. Lymphoma, 2002, 43, 1763-1768.

7 For the construction of $\mathrm{C} 2-\mathrm{C} 3^{\prime}$ biindolyl, please see: $(a)$ A. Pezzella, L. Panzella, A. Natangelo, M. Arzillo, A. Napolitano and M. d'Ischia, J. Org. Chem., 2007, 72, 9225-9230; (b) Z.-J. Liang, J. L. Zhao and Y. H. Zhang, J. Org. Chem., 2010, 75, 170-177; (c) Y. X. Li, K. G. Ji, H. X. Wang, S. Ali and Y. M. Liang, J. Org. Chem., 2011, 76, 744-747.

8 For the construction of C3-C3' biindolyl, please see: (a) Y. Li, W. H. Wang, S. D. Yang, B. J. Li, C. Feng and Z. J. Shi, Chem. Commun., 2010, 46, 4553-4555; (b) T. M. Niu and Y. H. Zhang, Tetrahedron Lett., 2010, 51, 6847-6851.

9 For the construction of $\mathrm{C} 2-\mathrm{C} 2$ ' biindolyl, please see: $(a)$ A. Pezzella, L. Panzella, O. Crescenzi, A. Napolitano, S. Navaratman, R. Edge, E. J. Land, V. Barone and M. D'lschia, J. Am. Chem. Soc., 2006, 128, 15490-15498; (b) P. A. Keller, N. R. Yepuri, M. J. Kelso, M. Mariani, B. W. Skelton and A. H. White, Tetrahedron, 2008, 64, 7787-7795; (c) X. H. Xu, G. K. Liu, A. Azuma, E. Tokunaga and N. Shibata, Org. Lett., 2011, 13, 4854-4857; (d) S. Liu and X. J. Hao, Tetrahedron Lett., 2011, 52, 5640-5642; (e) L. Panzella, A. Pezzella, A. Napolitano and M. D'lschia, Org. Lett., 2007, 9, 1411-1414; $(f)$ C. A. Meric, Y. You, D. M. McInnes, A. L. Zechman, M. M. Miller and Q. L. Deng, Tetrahedron, 2001, 57, 5199-5212; $(g)$ W. J. Zhang, Z. Liu, S. M. Li, T. T. Yang, Q. B. Zhang, L. Ma, X. P. Tian, H. B. Zhang, C. G. Huang, S. Zhang, J. H. Ju, Y. M. Shen and C. S. Zhang, Org. Lett., 2012, 14, 3364-3367; (h) N. R. Yepuri, R. Haritakul, P. A. Keller, B. W. Skelton and A. H. White, Tetrahedron Lett., 2009, 50, 2501-2504.

10 (a) D. Lenoir, Angew. Chem., Int. Ed., 2006, 45, 3206-3210; (b) S. S. Stahl, Science, 2005, 309, 1824-1826; (c) Y. H. Kuang, H. Rokubuichi, Y. Nabae, T. Hayakawa and M. Kakimoto, Adv. Synth. Catal., 2010, 352, 2635-2642.

11 For reviews on the application of TEMPO and its derivatives in organic synthesis, see: (a) R. A. Sheldon, I. W. C. E. Arends, G. J. T. Brink and A. Dijksman, Acc. Chem. Res., 2002, 35, 774-781; (b) R. A. Sheldon and I. W. C. E. Arends, Adv. Synth. Catal., 2004, 346, 10511071; (c) J. M. Bobbitt, C. Bruckner and N. Merbouh, Org. React., 2009, 74, 103-424; (d) C. Bruckner, in Stable Radicals, ed. R. G. Hicks, John Wiley, United Kingdom, 2010, pp. 433-456; (e) L. Tebben and A. Studer, Angew. Chem., Int. Ed., 2011, 50, 5034-5068; (f) R. Ciriminna and M. Pagliaro, Org. Process Res. Dev., 2010, 14, 245-251; $(g)$ O. Garcia-Mancheno and T. Stopka, Synthesis, 2013, 45, 1602-1611; (h) Z. G. Zhou and L. X. Liu, Curr. Org. Chem., 2014, 18, 459-474.

12 (a) F. Lin, Y. Chen, B. S. Wang, W. B. Qin and L. X. Liu, $R S C$ $A d v .$, 2015, 5, 37018-37022; (b) W. B. Qin, Q. Chang, Y. H. Bao, N. Wang, Z. W. Chen and L. X. Liu, Org. Biomol. Chem., 2012, 10, 8814-8821; (c) Y. H. Bao, J. Y. Zhu, W. B. Qin, Y. B. Kong, Z. W. Chen, S. B. Tang and 
L. X. Liu, Org. Biomol. Chem., 2013, 11, 7938-7945; (d) W. B. Qin, J. Y. Zhu, Y. B. Kong, Y. H. Bao, Z. W. Chen and L. X. Liu, Org. Biomol. Chem., 2014, 12, 4252-4259; (e) W. B. Qin, Q. Chang, H. Q. Luo, Y. H. Bao, Z. W. Chen and L. X. Liu, Curr. Org. Synth., 2013, 10, 492-499.

13 (a) C. Ganachaud, V. Garfagnoli, T. Tron and G. Iacazio, Tetrahedron Lett., 2008, 49, 2476-2478; (b) J. Bergman,
S. Bergman and J. O. Lindström, Tetrahedron Lett., 1998, 39, 4119-4122; (c) Y. H. Liu and W. W. McWhorter Jr, J. Org. Chem., 2003, 68, 2618-2622; (d) P. Astolfi, M. Panagiotaki, C. Rizzoli and L. Greci, Org. Biomol. Chem., 2006, 4, 3282-3290. 